\title{
Factors Influencing the Photocatalytic Degradation of Reactive Yellow 145 by $\mathrm{TiO}_{2}$-Coated Non-Woven Fibers
}

\author{
Said Alahiane*, Samir Qourzal, Mahmoud El Ouardi, Abdelhadi Abaamrane, Ali Assabbane \\ Physical Chemistry Laboratory, Photocatalysis and Environment Team, Department of Chemistry, \\ Faculty of Science, Ibn Zohr University, Agadir, Morocco \\ Email: ${ }^{*}$ alahiansaid@gmail.com
}

Received 9 April 2014; revised 12 May 2014; accepted 20 May 2014

Copyright @ 2014 by authors and Scientific Research Publishing Inc.

This work is licensed under the Creative Commons Attribution International License (CC BY). http://creativecommons.org/licenses/by/4.0/

c) (i) Open Access

\section{Abstract}

The photocatalytic degradation of the synthetic textile dye Reactive Yellow 145 (RY 145) in aqueous solution, using $\mathrm{TiO}_{2}$ coated non-woven fibers as photocatalyst, under UV-lamp irradiation, was studied. The effects of the operational parameters such as initial dye concentration, $\mathrm{pH}$, addition of oxidant hydrogen peroxide and addition of ethanol on the reaction rate were investigated. The effect of some inorganic ions such as $\mathrm{SO}_{4}^{2-}, \mathrm{Cl}^{-}, \mathrm{NO}_{3}^{-}, \mathrm{CH}_{3} \mathrm{COO}^{-}, \mathrm{HCO}_{3}^{-}$and $\mathrm{HPO}_{4}^{2-}$, commonly present in real effluents, on the photodegradation of RY 145 was also examined. The experimental results showed that the photocatalytic degradation rate was favoured by a high concentration of solution in respect to Langmuir-Hinshelwood model. The maximum rate of complete decolorization of $\mathrm{RY} 145$ was observed in the acidic medium at $\mathrm{pH} 3$. The presence of $\mathrm{SO}_{4}^{2-} \mathrm{and}^{-}$ anions led to an increase of the effectiveness of the photocatalytic degradation. However, the presence of $\mathrm{CH}_{3} \mathrm{COO}^{-}, \mathrm{HCO}_{3}^{-}$and $\mathrm{HPO}_{4}^{2-}$ anions decreased differently the photodegradation reaction rate. $\mathrm{TiO}_{2} / \mathrm{UV}$ process was proved to be capable of the complete degradation of the RY 145 .

\section{Keywords}

Photocatalytic Degradation, Immobilized $\mathrm{TiO}_{2}$, Reactive Yellow 145, Water Treatment

\section{Introduction}

Reactive dyes have been most commonly used due to their advantages such as better dyeing processing condi-

*Corresponding author.

How to cite this paper: Alahiane, S., et al. (2014) Factors Influencing the Photocatalytic Degradation of Reactive Yellow 145 by $\mathrm{TiO}_{2}$-Coated Non-Woven Fibers. American Journal of Analytical Chemistry, 5, 445-454. 
tions and bright colors. Generally, reactive dyes exhibit a wide range of different chemical structures, primarily based on substituted aromatic and heterocylic groups [1] [2]. However, the release of these colored wastewaters in the environment is a considerable source of non-aesthetic pollution and eutrophication [3]. It is well known that some azo dyes and degradation products such as aromatic amines are highly carcinogenic [4]. Since reactive dyes are highly soluble in water, their removal from wastewater is difficult by conventional coagulation and activated sludge processes [5]. Recently, there has been a considerable interest in the utilization of advanced oxidation processes (AOPs) for the complete destruction of dyes [6]-[11].

Heterogeneous photocatalysis (one kind of AOPs) has been considered as a cost effective alternative for the purification of dye containing wastewater [8] [9]. Moreover, recent studies have demonstrated that photocatalysis can be used to mineralize organic compounds or degrade dyes under UV irradiation [12]-[15]. Titanium dioxide $\left(\mathrm{TiO}_{2}\right)$ is one of the most preferable semiconductors for the photocatalytic process [16]-[19]. The mechanism constituting heterogeneous photocatalytic oxidation processes has been discussed extensively in the literature [20] [21]. When titanium dioxide $\left(\mathrm{TiO}_{2}\right)$ is illuminated with light of band gap energy (3.2 eV), electrons in conduction band $\left(\mathrm{e}_{\mathrm{CB}}^{-}\right)$and holes in valence band $\left(\mathrm{h}_{\mathrm{VB}}^{+}\right)$are produced according to:

$$
\mathrm{TiO}_{2}+\mathrm{h} v \rightarrow \mathrm{h}_{\mathrm{VB}}^{+}+\mathrm{e}_{\mathrm{CB}}^{-}
$$

These charge carries can recombine, or the holes can be scavenged by oxidizing species (for example, $\mathrm{H}_{2} \mathrm{O}$, $\mathrm{OH}^{-}$), and electron by reducible species (for example, $\mathrm{O}_{2}$ ) in the solution:

$$
\begin{gathered}
\mathrm{h}_{\mathrm{VB}}^{+}+\mathrm{H}_{2} \mathrm{O} \rightarrow \mathrm{OH}^{\circ}+\mathrm{H}^{+} \\
\mathrm{h}_{\mathrm{VB}}^{+}+\mathrm{OH}^{-} \rightarrow \mathrm{OH}^{\circ} \\
\mathrm{e}_{\mathrm{CB}}^{-}+\mathrm{O}_{2} \rightarrow \mathrm{O}_{2}^{-}
\end{gathered}
$$

The hydroxyl radical (like $\mathrm{OH}^{\circ}$ ) is a highly reactive oxidizing reagent and can decompose most organic contaminants [22] [23].

However, the obligation to separate the small $\mathrm{TiO}_{2}$ particles from the suspension after treatment limits the process development. Alternatively, the catalyst may be immobilized onto a suitable solid inert material, which eliminates the catalyst removal step [4] [24].

In this work, the photocatalytic degradation of Reactive Yellow dye (RY 145), selected as a model organic pollutant, was investigated using a new photocatalytic material, which consists of $\mathrm{TiO}_{2}$ supported on natural and synthetic non-woven fibers. The investigation of factors that influenced the dye photocatalytic removal was carried out.

\section{Materials and Methods}

\subsection{Materials}

All chemicals used in the investigation were of reagent grade and were used without further purification.

The immobilized photocatalyst used in this study consists in PC500 titania by Millennium inorganic chemicals (anatase: $>99 \%$, specific surface area $350-400 \mathrm{~m}^{2} / \mathrm{g}$, crystallites mean size $=5-10 \mathrm{~nm}$ ). Titania PC500 was coated on non-woven fibers (natural and synthetic fibers $254 \mu \mathrm{m}$ of thickness) using an inorganic binder. The binder was an aqueous dispersion of colloidal $\mathrm{SiO}_{2}$. A specific surface area extender (zeolite, $2000 \mathrm{~m}^{2} / \mathrm{g}$ ) was used to increase adsorption properties of the photocatalyst.

The RY 145 was obtained from a textile firm as a commercial available dye (C.I. Reactive Yellow 145). The molecular structure and other properties of RY 145 are given in Table 1. Solutions were prepared by dissolving requisite quantity of the dye in distilled water. The $\mathrm{pH}$ was adjusted to a given value in the range 3 - 11.5 by addition of $\mathrm{HNO}_{3}(1 \mathrm{~N})$ or $\mathrm{NaOH}(1 \mathrm{~N})$ and was measured using a Schott Titroline $\mathrm{pH}$-meter. The $\mathrm{H}_{2} \mathrm{O}_{2}$ solution (30\%) was obtained from Merck.

\subsection{Photocatalytic Reactor}

Irradiation was performed in a cylindrical batch reactor opened at air, $8 \mathrm{~cm}$ in diameter and $12 \mathrm{~cm}$ in working height. The water jacket has a diameter of $5 \mathrm{~cm}$, contains a UV lamp, and permits water circulation. The photocatalytic reactor was covered inside with $(11 \mathrm{~cm} \times 25 \mathrm{~cm})$ of the photocatalyst and was exposed to a luminous 
Table 1. Properties of RY 145 dye.

\begin{tabular}{cc}
\hline Name & Reactive Yellow 145 (RY 145) \\
Nature & Anionic reactive dye \\
Molecular weight $(\mathrm{g} / \mathrm{mol})$ \\
Reactive group $(\mathrm{nm})$
\end{tabular}

source (an HPK 125 W Philips ultraviolet lamp with a wavelength maximum of $365 \mathrm{~nm}$ ), placed in axial position inside the water jacket. The reactor was stirred continuously at a low setting, $100 \mathrm{rpm}$, by a magnetic stirrer.

\subsection{Procedure and Analysis}

The photodegradation experiments were carried out by loading $500 \mathrm{ml}$ of the dye solutions in the photocatalytic reactor. The effect of initial concentration was obtained with different initial dye concentrations $(5-40 \mathrm{mg} / \mathrm{l})$ at initial $\mathrm{pH}$. The effect of $\mathrm{pH}$ was carried out by varying the initial $\mathrm{pH}$ of aqueous solution from 3 to 11.5, with an initial concentration of $30 \mathrm{mg} / \mathrm{l}$. In all experiments, the solution of RY $145 \mathrm{~L}$ was magnetically stirred in presence of $\mathrm{TiO}_{2}$ in the dark during $45 \mathrm{~min}$ to reach the adsorption equilibrium before UV irradiation. The temperature was maintained at $20^{\circ} \mathrm{C}$.

The RY 145 aqueous solutions were filtered by Millipore membrane filter type $0.45 \mu \mathrm{m}$, and the concentrations were determined from UV-Vis absorbance characteristic with the calibration curve method. A Jasco V-630 UV/Visible spectrophotometer was used.

The percentage decolorization was calculated as follows:

$$
\% \text { Decolorization }=100 \times\left(\mathrm{C}_{\mathrm{o}}-\mathrm{C}\right) / \mathrm{C}_{\mathrm{o}}
$$

where $\mathrm{C}_{0}=$ initial concentration of dye solution, $\mathrm{C}=$ concentration of dye solution after photoirradiation.

\section{Results and Discussion}

\subsection{Effect of Initial Concentration}

The effects of the initial concentration of RY 145 dye on the photocatalytic efficiency were investigated with concentrations from 5 to $40 \mathrm{mg} / \mathrm{l}$ (Figure 1).

It was found that on increasing the dye concentration the degradation efficiencies of dye decreases. Hence, the photo-oxidation process will work faster at a low concentration of pollutants. These results are in agreement with previous reports [17] [25] [26] that photodegradation of textile dye RY 145 decreased with increasing concentrations. At high concentrations of dye, the deeper colored solution would be less transparent to UV light and the dye molecules may absorb a significant amount of UV light causing less light to reach the catalyst and thus reducing the $\mathrm{OH}^{\circ}$ radical formation.

The effect of the initial concentration of the initial rate of the photocatalytic degradation of RY 145 is represented by curve of Figure 2. These initial results indicate that the degradation rate increases with the initial concentration. The shape of the curves is similar to that obtained in the kinetic model of Langmuir-Hinshelwood (L-H) [27] and expression of the initial rate of which is given by the following equation:

$$
\mathrm{r}_{\mathrm{o}}=\frac{k \mathrm{KC}_{\mathrm{o}}}{1+\mathrm{KC}_{\mathrm{o}}}
$$

where $\mathrm{r}_{\mathrm{o}}$ is the initial degradation rate of RY $145(\mathrm{mg} / \mathrm{l} \mathrm{min}), k$ is the observed degradation rate constant relating to $\mathrm{TiO}_{2}$-catalysed primary oxidation events on a surface monolayer $(\mathrm{mg} / \mathrm{l} \mathrm{min})$, and $\mathrm{K}$ is a pseudo-equilibrium 


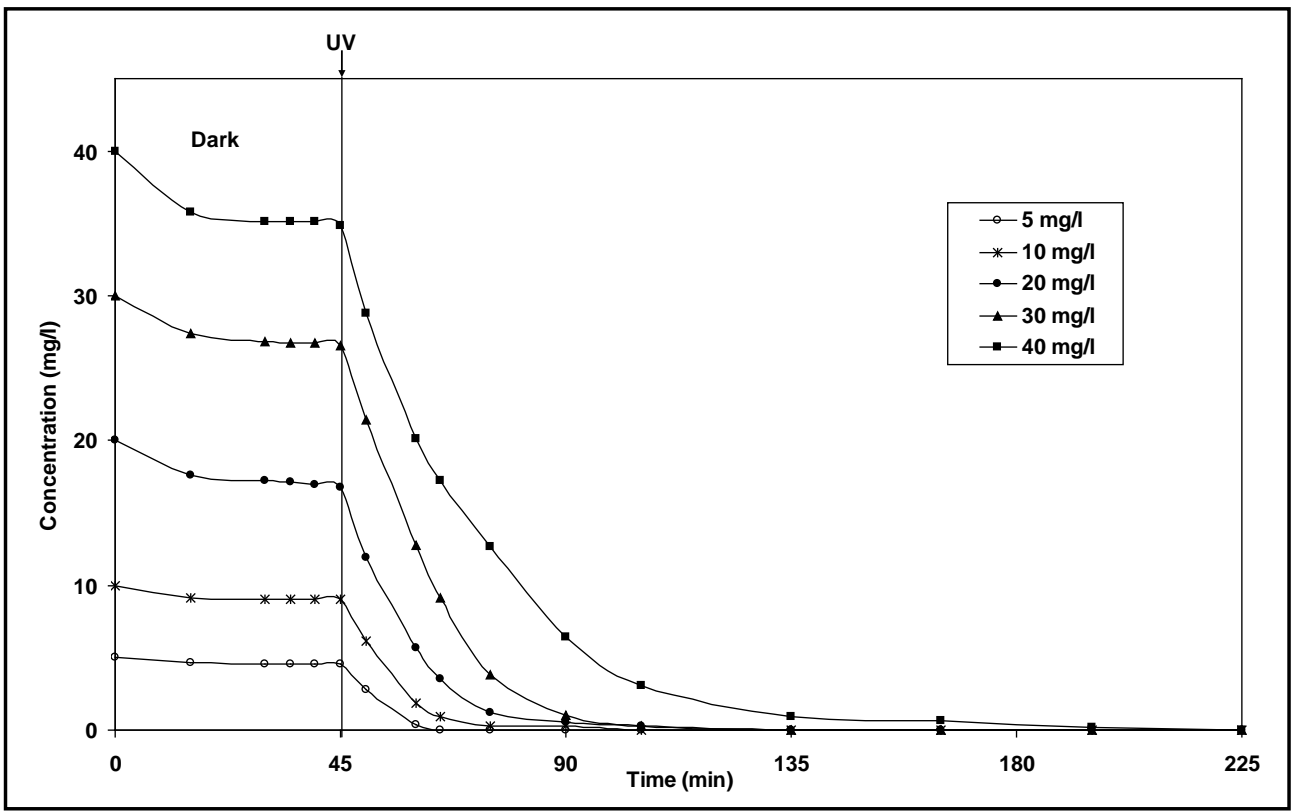

Figure 1. Effect of the initial RY 145 concentration on photodegradation efficiency.

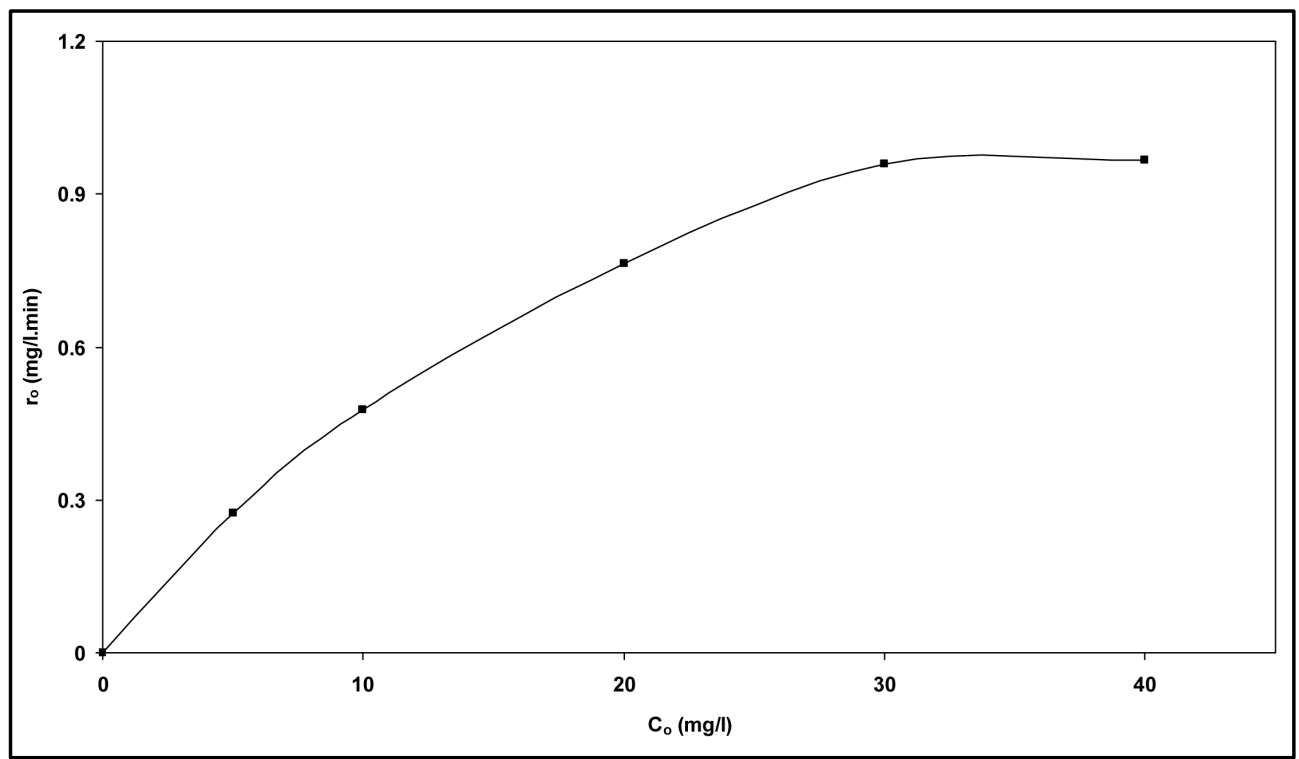

Figure 2. Effect of initial RY 145 concentration on the initial rate of degradation.

constant related to the monolayer adsorption ( $\mathrm{l} / \mathrm{mg})$. Rearrangement Equation (5) it can be observed that linear relationship exists between the reciprocal initial rate and the reciprocal initial substrate concentration (Equation (6)):

$$
\frac{1}{\mathrm{r}_{\mathrm{o}}}=\frac{1}{k}+\frac{1}{k \mathrm{KC}_{\mathrm{o}}}
$$

In Figure 2, it is shown that the initial degradation rate $\left(r_{0}\right)$ increases at the beginning of the run, when the concentration of RY 145 is increased until it attains a plateau, at around $30 \mathrm{mg} / 1$. This behaviour indicates saturation-type Langmuir kinetics. This is confirmed by the linear plots of $1 / \mathrm{r}_{0}$ versus $1 / \mathrm{C}_{0}$ (see Figure 3 ). The calculated value of $\mathrm{K}$ and $k$ were $0.037 \mathrm{l} / \mathrm{mg}$ and $1.74 \mathrm{mg} / \mathrm{l} . \mathrm{min}$, respectively. Such a Langmuir-Hinshelwood type relationship between the initial degradation rate and the concentration, has been also reported by other au- 


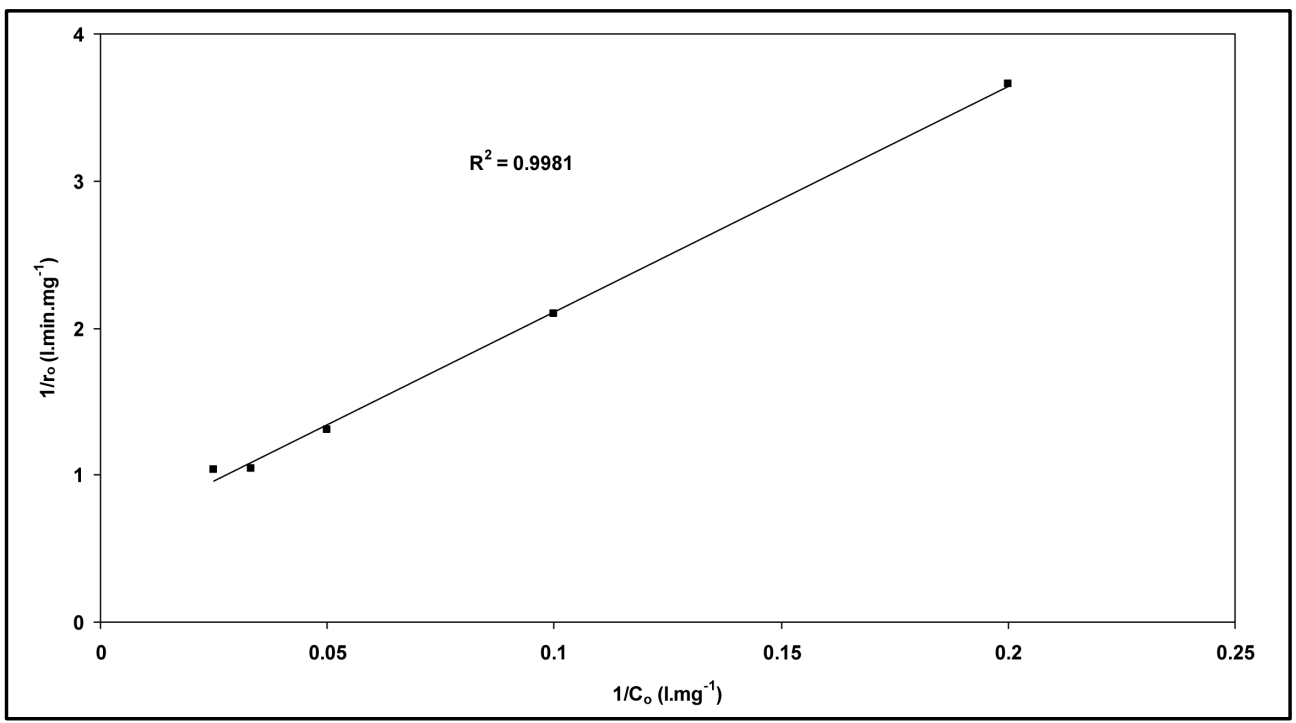

Figure 3. The linear transformation of $1 / \mathrm{r}_{0}$ vs. $1 / \mathrm{C}_{0}$.

thors [27] [28]. This type of reaction kinetics suggests that the adsorption plays a key role in the photocatalytic degradation mechanism.

\subsection{Effect of $\mathrm{pH}$}

An important parameter in the photocatalytic reactions taking place on the particulate surfaces is the $\mathrm{pH}$ of the solution, since it dictates the surface charge properties of the photocatalyst and size of aggregates it forms. It is well known that $\mathrm{pH}$ value has an influence on the kinetic of degradation of some organic compounds in photocatalytic processes [27]-[29]. Therefore, the degradation of the pollutant was studied at different $\mathrm{pH}$ values (in the range 3 - 11.5). Figure 4 shows the color removal efficiency of RY 145 as a function of pH. The experimental results revealed that higher degradation of RY 145 was found to be in acidic conditions. The maximum decolorization was observed at $\mathrm{pH}$ 3. This may be attributed to the electrostatic interactions between the positive catalyst surface and dye anions leading to strong adsorption of the latter on the metal oxide support. Similar behavior has also been reported for the photocatalytic efficiency of $\mathrm{TiO}_{2}$ for decolorization of azo dyes [16] [29] [30]. Moreover, the positive holes are considered as the major oxidation species at low $\mathrm{pH}$ which react with hydroxide ions forming hydroxyl radicals, thus the efficiency of process is enhanced. At increased $\mathrm{pH}$, there is a columbic repulsion between negatively charged surface of catalyst and the hydroxide anions which prevent the formation of $\mathrm{OH}^{\circ}$ and decrease the photocatalytic degradation [31].

\subsection{Effect of Addition of $\mathrm{H}_{2} \mathrm{O}_{2}$}

The addition of $\mathrm{H}_{2} \mathrm{O}_{2}$ was regarded as a good parameter for enhancement of photocatalytic degradation process [32]. The results as shown in Figure 5, indicate that the hydrogen peroxide had accelerated the photocatalytic degradation of RY 145. The photocatalytic degradation rate of RY 145 increased when hydrogen peroxide concentration increased from 0 to $3 \mathrm{~mol} / \mathrm{l}$. The maximum degradation is achieved at $\mathrm{H}_{2} \mathrm{O}_{2}$ concentration of $3 \mathrm{~mol} / \mathrm{l}$. This could be due to the production of hydroxyl radical $\mathrm{OH}^{\circ}$ by photodissociation of $\mathrm{H}_{2} \mathrm{O}_{2}$ which is acting as strong oxidant and as electron scavengers [33].

$$
\begin{gathered}
\mathrm{H}_{2} \mathrm{O}_{2}+\mathrm{e}^{-} \rightarrow \mathrm{OH}^{-}+\mathrm{OH}^{\circ} \\
\mathrm{OH}^{\circ}+\text { dye } \rightarrow \text { dye intermediate } \\
\mathrm{OH}^{\circ}+\text { dye intermediate } \rightarrow \text { mineralization product }
\end{gathered}
$$

Moreover increasing of hydrogen peroxide concentration, more than $3 \mathrm{~mol} / \mathrm{l}$, decreased the rate of photocatalytic degradation that could be due to by scavenging effect. However, High concentration of $\mathrm{H}_{2} \mathrm{O}_{2}$ inhibits catalytic activity as $\mathrm{H}_{2} \mathrm{O}_{2}$ is adsorbed onto $\mathrm{TiO}_{2}$ [11]. 


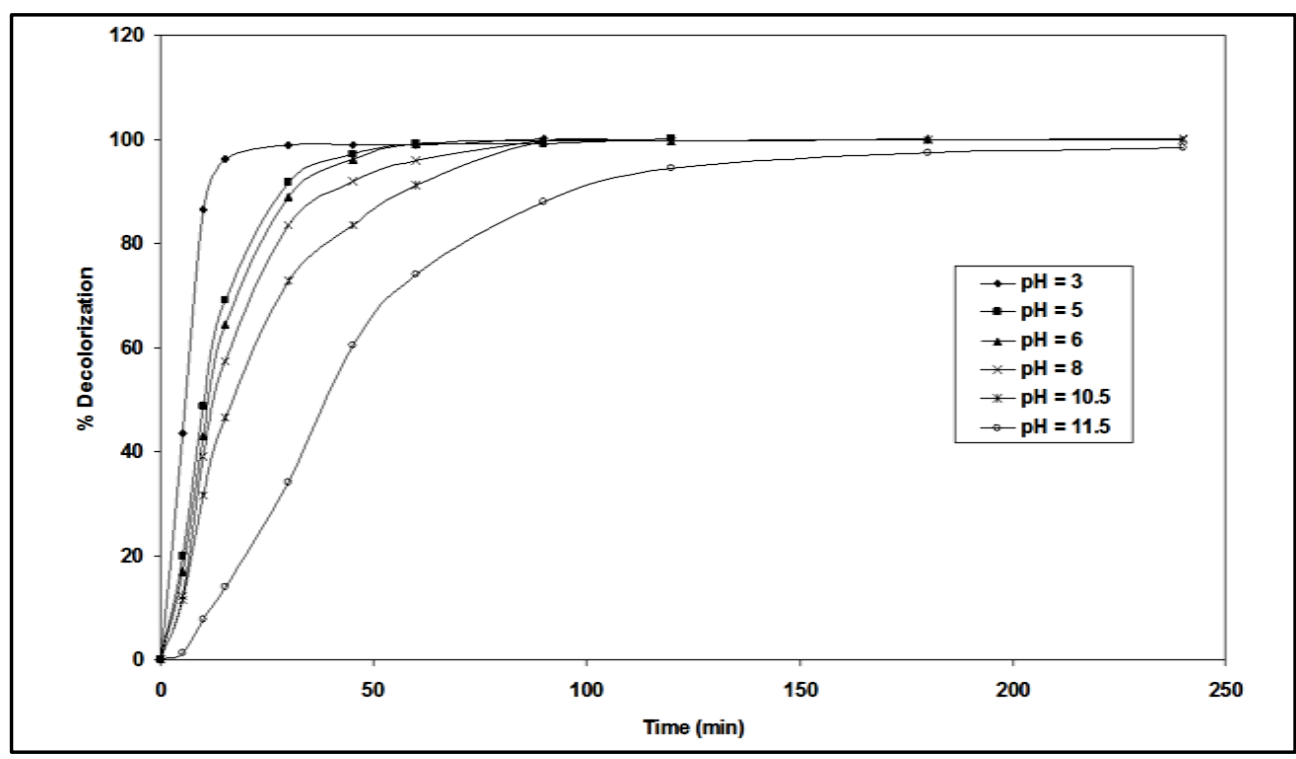

Figure 4. Effect of $\mathrm{pH}$ on decolorization rate of $\mathrm{RY} 145$ dye $\left(\mathrm{C}_{\mathrm{o}}=30 \mathrm{mg} / \mathrm{l}\right)$.

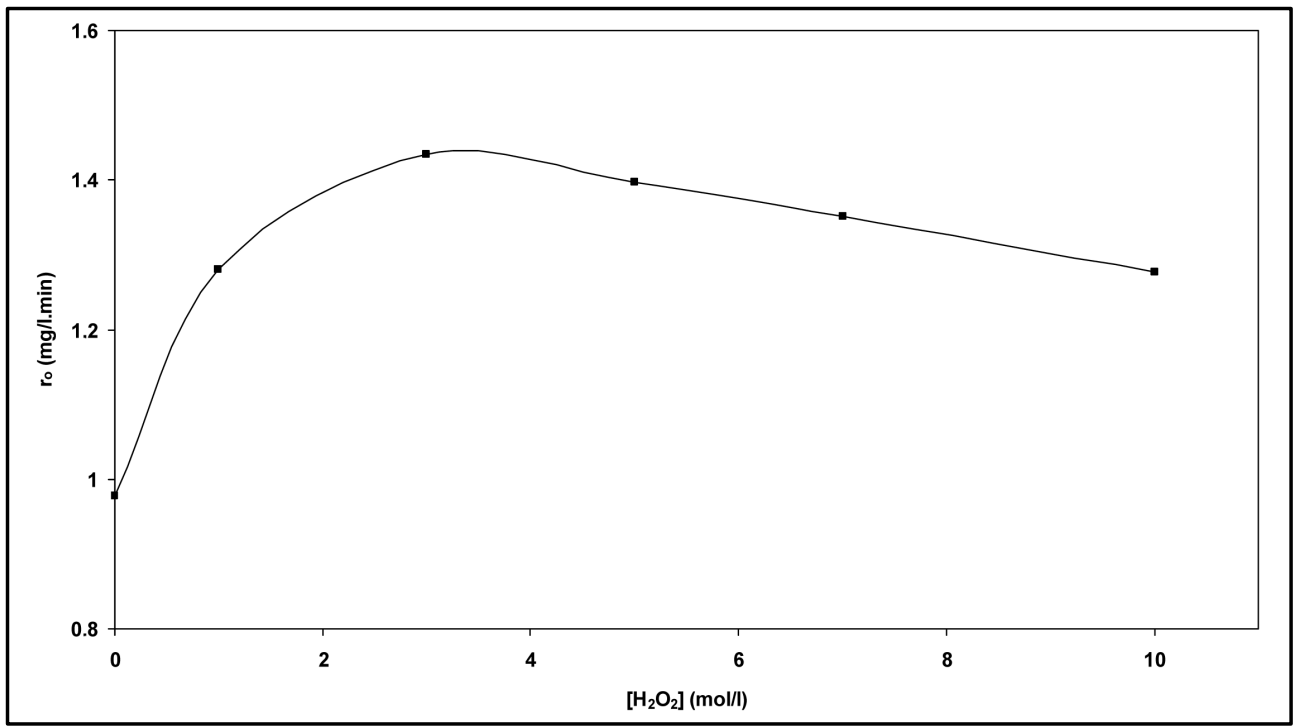

Figure 5. Effect of $\mathrm{H}_{2} \mathrm{O}_{2}$ concentration on photocatalytic degradation of RY $145\left(\mathrm{C}_{0}=30 \mathrm{mg} / \mathrm{l}\right)$.

$$
\begin{gathered}
\mathrm{H}_{2} \mathrm{O}_{2}+\mathrm{OH}^{\circ} \rightarrow \mathrm{H}_{2} \mathrm{O}+\mathrm{HO}_{2}^{\circ} \\
\mathrm{HO}_{2}^{\circ}+\mathrm{OH}^{\circ} \rightarrow \mathrm{H}_{2} \mathrm{O}+\mathrm{O}_{2}
\end{gathered}
$$

\subsection{Effect of Ethanol}

It is well known that in the photocatalytic degradation process two main species have the major contributions; electrons and holes $\left(\mathrm{h}_{\mathrm{VB}}^{+}, \mathrm{e}_{\mathrm{CB}}^{-}\right)$and hydroxyl radicals. In order to evaluate these two paths, experiments were performed by adding different amounts of ethanol to the solution. Alcohols such as ethanol are commonly used to quench hydroxyl radicals [11] [32] [34]. As it is observed from Figure 6, adding small amounts of ethanol, up to $2 \mathrm{ml}$ of ethanol, decreases the degradation efficiency of RY 145. On the other hand, adding extra amount of ethanol leads to a mild increase in the process efficiency due to the formation of ethoxy radicals $\left(\mathrm{C}_{2} \mathrm{H}_{5} \mathrm{O}^{\circ}\right)$ from direct photocatalytic oxidation of ethanol; meanwhile, the ethanol molecules can produce hydroxyl radicals in direct photolysis with respect to the level of C-O energy bond. 


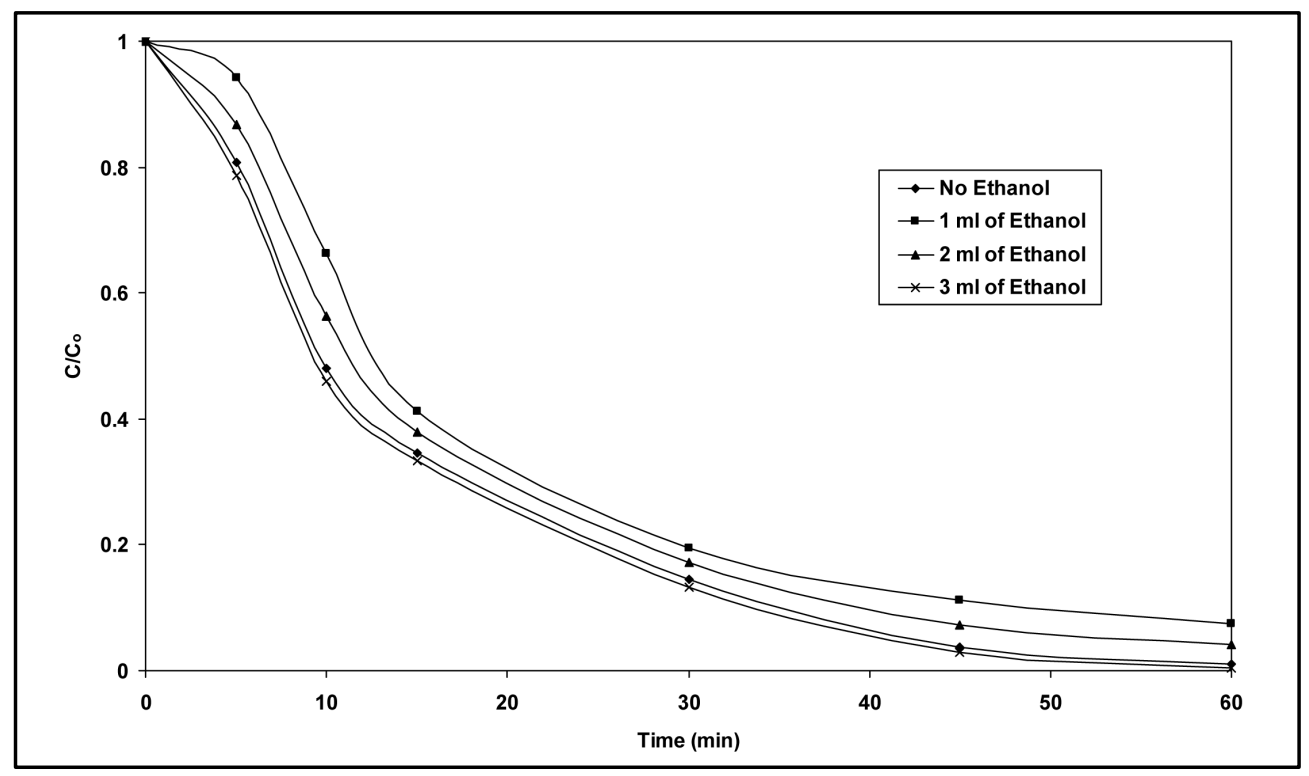

Figure 6. Effect of ethanol on the photocatalytic degradation of RY $145\left(C_{0}=30 \mathrm{mg} / 1\right)$.

\subsection{Effect of Some Ions}

The photocatalytic degradation of dyes is also performed in the presence of inorganic anions [35] [36]. They are generally present in industrial discharges with values depending on the nature of the effluent. In this study, the effect of $\mathrm{SO}_{4}^{2-}, \mathrm{Cl}^{-}, \mathrm{NO}_{3}^{-}, \mathrm{CH}_{3} \mathrm{COO}^{-}, \mathrm{HCO}_{3}^{-}$and $\mathrm{HPO}_{4}^{2-}$ (sodium salts) in the order of $10^{-3} \mathrm{~mol} / \mathrm{l}$ was investigated. As shown in Figure 7, the presence of $\mathrm{SO}_{4}^{2-}$ and $\mathrm{Cl}^{-}$anions leads to an increase of the effectiveness of the photocatalytic degradation. However, the presence of $\mathrm{CH}_{3} \mathrm{COO}^{-}, \mathrm{HCO}_{3}^{-}$and $\mathrm{HPO}_{4}^{2-}$ anions decreases differently the photocatalytic efficiency.

For $\mathrm{HPO}_{4}^{2-}$ ions, it's well known that they are strongly adsorbed on the surface of $\mathrm{TiO}_{2}$, and therefore, they compete with the adsorption of RY 145 on the surface of the photocatalyst. They can also scavenge $\mathrm{OH}^{\circ}$ to form the corresponding anion radicals $\mathrm{HPO}_{4}^{-\circ}$, which leads to the decrease of the oxidation process [36].

The inhibitory effect of $\mathrm{HCO}_{3}^{-}$ions can be explained by a competition with the adsorption of dye on the surface of $\mathrm{TiO}_{2}$ (capture $\mathrm{OH}^{\circ}$ radicals to produce $\mathrm{CO}_{3}^{-\circ}$ less reactive).

$$
\mathrm{HCO}_{3}^{-}+\mathrm{OH}^{\circ} \rightarrow \mathrm{CO}_{3}^{-\circ}+\mathrm{H}_{2} \mathrm{O}
$$

Some authors explain this effect by blocking the active sites of the catalyst [37].

The reduction of the photocatalytic degradation in presence of $\mathrm{CH}_{3} \mathrm{COO}^{-}$, which is used to reduce the alkalinity of the effluent in dyeing section, can be explained by the "photo-kolbe" reaction (Equation (13)) [38], which inhibits the formation $\mathrm{OH}^{\circ}$ radicals via Equations (14) and (15) on the surface of the photocatalyst.

$$
\begin{aligned}
\mathrm{CH}_{3} \mathrm{COO}^{-}+\mathrm{h}^{+} & \rightarrow \mathrm{CH}_{3}^{\circ}+\mathrm{CO}_{2} \\
\mathrm{~h}^{+}+\mathrm{H}_{2} \mathrm{O} & \rightarrow \mathrm{OH}^{\circ}+\mathrm{H}^{+} \\
\mathrm{h}^{+}+\mathrm{OH}^{-} & \rightarrow \mathrm{OH}^{\circ}
\end{aligned}
$$

The effect of $\mathrm{Cl}^{-}$on the oxidation process can be explained by the result of the reaction of photo-produced $\mathrm{OH}^{\circ}$ with $\mathrm{Cl}^{-}[28]$ :

$$
\mathrm{OH}^{\circ}+\mathrm{Cl}^{-} \rightarrow \mathrm{Cl}^{\circ}+\mathrm{OH}^{-}
$$

The $\mathrm{Cl}^{\circ}$ radicals are in principle also capable of oxidizing pollutants and to participate in process of degradation. However, the generation of $\mathrm{Cl}^{\circ}$ radicals leads also to the formation of chlorinated organic compounds, which are known as very harmful substances.

For $\mathrm{SO}_{4}^{2-}$ ions, they are adsorbed in the surface of $\mathrm{TiO}_{2}$ and consequently react with photo-induced holes $\left(\mathrm{h}^{+}\right)$ [38]: 


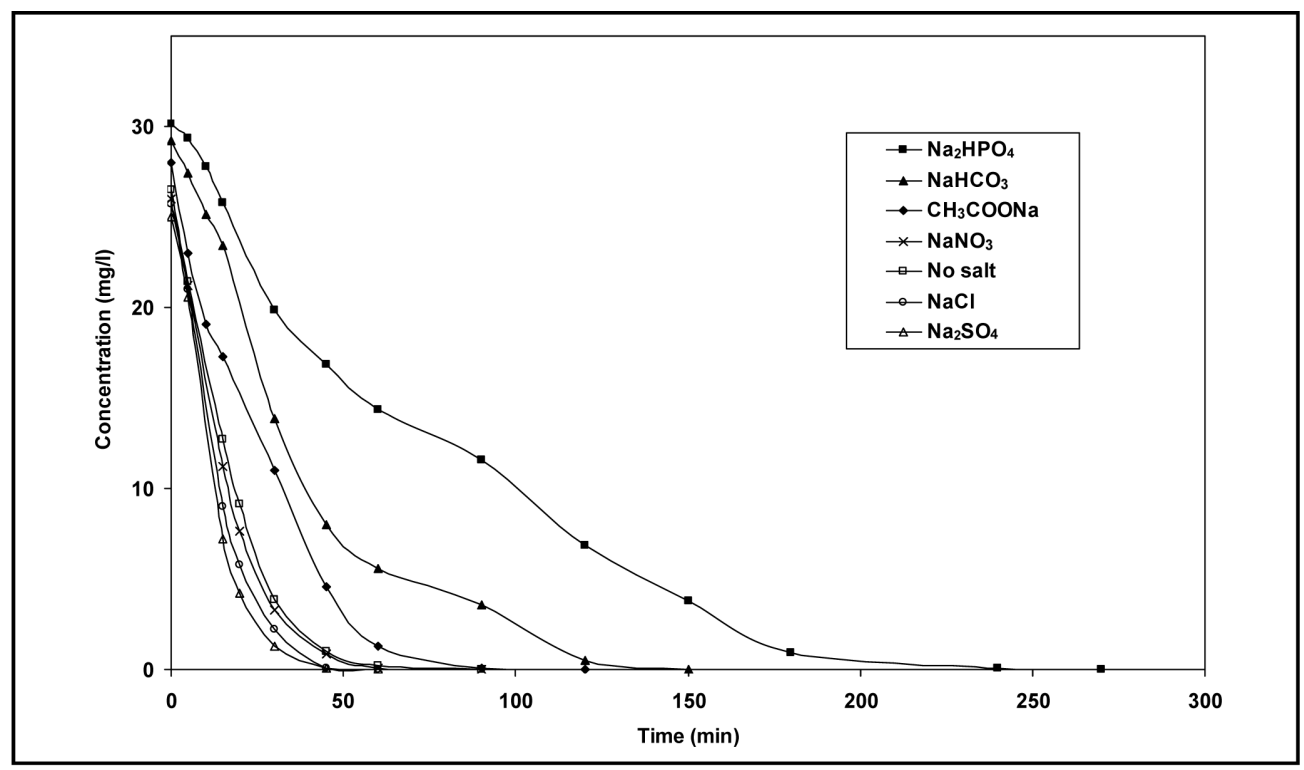

Figure 7. Effect of anions on the photodegradation of RY $145\left(\mathrm{C}_{0}=30 \mathrm{mg} / \mathrm{l}\right)$.

$$
\mathrm{h}^{+}+\mathrm{SO}_{4}^{2-} \rightarrow \mathrm{SO}_{4}^{-\circ}
$$

The sulphate radical anion $\left(\mathrm{SO}_{4}^{-\circ}\right)$ formed is a strong oxidant, and engages in the three possible modes of reactions with organic compounds: 1) by abstracting a hydrogen atom from saturated carbon; 2) by addition to unsaturated or aromatic carbon; and 3) by removing one electron from the carboxylate anion and from certain neutral molecules.

Regarding nitrate ions, it has been shown that they adsorb weakly on the surface of titanium dioxide and, thus, little effect on photodegradation of RY 145. According to Lucas Vaz et al. [39], these ions generate $\mathrm{OH}^{\circ}$ radicals in the presence of sunlight according to the following equation:

$$
\mathrm{NO}_{3}^{-} \stackrel{\mathrm{hv}}{\longrightarrow}\left(\mathrm{NO}_{3}^{-}\right) * \stackrel{\mathrm{H}_{2} \mathrm{O}}{\longrightarrow} \mathrm{NO}_{2}^{\circ}+\mathrm{OH}^{\circ}+\mathrm{OH}^{-}
$$

\section{Conclusion}

Photocatalysis has been ascertained to be a promising technique for the removal of dyes from industrial effluents. In the present investigation, a complete removal of reactive yellow 145 on $\mathrm{TiO}_{2}$ coated non-woven fibers has been processed with the help of Langmuir-Hinshelwood model. The study reveals that the photocatalytic degradation of synthetic wastewater of RY 145 dye made with $\mathrm{TiO}_{2}$ coated non-woven fibers depends on the initial concentration of dye, $\mathrm{pH}$, concentration of hydrogen peroxide, addition of the ethanol and inorganic ions. It was shown that complete degradation can be achieved. The maximum efficiency of decolorization is ac acidic $\mathrm{pH}$. The maximum amount of dark surface adsorption is observed at $\mathrm{pH}$ of 3 . Moreover, with addition of oxidant $\mathrm{H}_{2} \mathrm{O}_{2}$ into illuminated $\mathrm{TiO}_{2}$, a synergistic effect that leads to an enhancement and improvement of the efficiency of the process is observed. Our results showed that ethanol (2 ml) inhibited the photodegradation of dye; we concluded from the inhibitory effect of ethanol that hydroxyl radicals played a major role in photocatalytic degradation of RY 145 in the time. The presence of $\mathrm{SO}_{4}^{2-}$ and $\mathrm{Cl}^{-}$ions increased the photodegradation rate while, $\mathrm{CH}_{3} \mathrm{COO}^{-}, \mathrm{HCO}_{3}^{-}$and $\mathrm{HPO}_{4}^{2-}$ decreased the reaction rate. The use of $\mathrm{TiO}_{2}$ coated on non-woven fibers is an efficient photocatalyst to degrade textile dye avoiding the tedious filtration step.

\section{References}

[1] Lin, S.H. and Lai, C.L. (1999) Catalytic Oxidation of Dye Wastewater by Metal Oxide Catalyst and Granular Activated Carbon. Environment International, 25, 497-504. http://dx.doi.org/10.1016/S0160-4120(99)00015-X

[2] Aguedach, A., Brosillon, S., Morvan, J. and Lhadi, E.K. (2008) Influence of Ionic Strength in the Adsorption and During Photocatalysis of Reactive Black 5 azo Dye on $\mathrm{TiO}_{2}$ Coated on Non Woven Paper with $\mathrm{SiO}_{2}$ as a Binder. Journal 
of Hazardous Materials, 150, 250-256. http://dx.doi.org/10.1016/j.jhazmat.2007.04.086

[3] Konstantinou, I.K. and Albanis, T.A. (2004) $\mathrm{TiO}_{2}$-Assisted Photocatalytic Degradation of Azo Dyes in Aqueous Solution: Kinetic and Mechanistic Investigations: A Review. Applied Catalysis B: Environmental, 49, 1-14. http://dx.doi.org/10.1016/j.apcatb.2003.11.010

[4] Lachheb, H., Puzenat, E., Houas, A., Ksibi, M., Elaloui, E., Guillard, C and Herrmann, J.-M. (2002) Photocatalytic Degradation of Various Types of Dyes (Alizarin S, Crocein Orange G, Methyl Red, Congo Red, Methylene Blue) in Water by UV Irradiated Titania. Applied Catalysis B: Environmental, 39, 75-90. http://dx.doi.org/10.1016/S0926-3373(02)00078-4

[5] Zdemir, O., Armagan, B., Turan, M. and Çelik, M.S. (2004) Comparision of the Adsorption Characteristics of Azo Reactive Dyes on Mezoporous Minerals. Dyes Pigments, 62, 49-60. http://dx.doi.org/10.1016/j.dyepig.2003.11.007

[6] Kusvuran, E., Gulnaz, O., Irmak, S., Atanur, O.M., Yavuz, H.I. and Erbatur, O. (2004) Comparison of Several Advanced Oxidation Processes for the Decolorization of Reactive Red 120 Azo Dye in Aqueous Solution. Journal of Hazardous Materials, 109, 85-93. http://dx.doi.org/10.1016/j.jhazmat.2004.03.009

[7] Kusvuran, E., Irmak, S., Yavuz, H.I., Samil, A. and Erbatur, O. (2005) Comparison of Treatment Methods Efficiency on Decolorization and Mineralization of Reactive Black 5 Azo Dye. Journal of Hazardous Materials, 119, 109-116. http://dx.doi.org/10.1016/j.jhazmat.2004.11.017

[8] So, C.M., Cheng, M.Y., Yu, J.C. and Wong, P.K. (2002) Degradation of Azo Dye Procion Red MX-5B by Photocatalytic Oxidation. Chemosphere, 46, 905-912. http://dx.doi.org/10.1016/S0045-6535(01)00153-9

[9] Grzechulska, J. and Morawski, A.W. (2002) Photocatalytic Decomposition of Azo-Dye Acid Black 1 in Water over Modified Titanium Dioxide. Applied Catalysis B: Environmental, 36, 45-51. http://dx.doi.org/10.1016/S0926-3373(01)00275-2

[10] Mashkoura, M.S., Al-Kaimb, A.F., Ahmed, L.M. and Hussein, F.H. (2011) Zinc Oxide Assisted Photocatalytic Decolorization of Reactive Red 2 Dye. International Journal of Chemical Sciences, 9, 969-979.

[11] Maasoomeh, K., Nezameddin, D. and Soodabeh, S. (2010) Heterogeneos Photocatalytic Decolorization of Brown NG by $\mathrm{TiO}_{2}$-UV Process. Iranian Journal of Chemistry \& Chemical Engineering, 29, 19-26.

[12] Vautier, M., Guillard, C. and Herrmann, J.M. (2001) Photocatalytic Degradation of Dyes in Water: Case Study of Indigo and of Indigo Carmine. Journal of Catalysis, 201, 46-59. http://dx.doi.org/10.1006/jcat.2001.3232

[13] Zielinska, B., Grzechulska, J., Grzmil, B. and Morawski, A.W. (2003) The pH Influence on Photocatalytic Decomposition of Organic Dyes over A11 and P25 Titanium Dioxide. Applied Catalysis B: Environmental, 45, 293-300. http://dx.doi.org/10.1016/S0926-3373(03)00178-4

[14] Hachem, C., Bocquillon, F., Zahraa, O. and Bouchy, M. (2001) Decolorization of Textile Industry Wastewater by the Photocatalytic Degradation Process. Dyes Pigments, 49, 117-125. http://dx.doi.org/10.1016/S0143-7208(01)00014-6

[15] Noorjahan, M., Reddy, M.P., Kumari, V.D., Lavedrine, B., Boule, P. and Subrahmanyan, M. (2003) Photocatalytic Degradation of H-Acid over a Novel $\mathrm{TiO}_{2}$ Thin Film Fixed Bed Reactor and in Aqueous Suspensions. Journal of Photochemistry and Photobiology A: Chemistry, 156, 179-187. http://dx.doi.org/10.1016/S1010-6030(02)00408-2

[16] Barka, N., Qourzal, S., Assabbane, A., Nounah, A. and Ait-Ichou, Y. (2010) Photocatalytic Degradation of an Azo Reactive Dye, Reactive Yellow 84, in Water Using an Industrial Titanium Dioxide Coated Media. Arabian Journal of Chemistry, 3, 279-283. http://dx.doi.org/10.1016/j.arabjc.2010.06.016

[17] Elatmani, K., Afanga, H., Qourzal, S., Assabbane, A., Ait-Ichou, Y., Costa Pereira, J. and Emilia Azenha, M. (2011) Photocatalytic Degradation of Two Insecticides Lannate and Carbaryl with Supported $\mathrm{TiO}_{2}$. Annales de ChimieScience des Matériaux, 35, 269-282. http://dx.doi.org/10.3166/acsm.35.269-282

[18] Grzechulska, J. and Morawski, A.W. (2002) Photocatalytic Decomposition of Azo-Dye Acid Black 1 in Water over Modified Titanium Dioxide. Applied Catalysis B: Environmental, 36, 45-51. http://dx.doi.org/10.1016/S0926-3373(01)00275-2

[19] Vulliet, E., Chovelon, J.M., Guillard, C. and Herrmann, J.M. (2003) Factors Influencing the Photocatalytic Degradation of Sulfonylurea Herbicides by $\mathrm{TiO}_{2}$ Aqueous Suspension. Journal of Photochemistry and Photobiology A: Chemistry, 159, 71-79. http://dx.doi.org/10.1016/S1010-6030(03)00108-4

[20] Herrmann, J.M. (1995) Heterogeneous Photocatalysis: An Emerging Discipline Involving Multiphase Systems. Catalysis Today, 24, 157-164. http://dx.doi.org/10.1016/0920-5861(95)00005-Z

[21] Robert, D. and Malato, S. (2002) Solar Photocatalysis: A Clean Process for Water Detoxification. The Science of the Total Environment, 291, 85-97. http://dx.doi.org/10.1016/S0048-9697(01)01094-4

[22] D’Oliveira, J.C., Al-Sayyed, G. and Pichat, P. (1990) Photodegradation of 2- and 3-Chlorophenol in TiO $\mathrm{T}_{2} \mathrm{Aqueous}$ Suspensions. Environmental Science and Technology, 24, 990-996. http://dx.doi.org/10.1021/es00077a007

[23] Barka, N., Qourzal, S., Assabbane, A. and Ait-Ichou, Y. (2010) Kinetic Modeling of the Photocatalytic Degradation of 
Methyl Orange by Supported $\mathrm{TiO}_{2}$. Journal of Environmental Science and Engineering, 4, 1-5.

[24] Guillard, C., Lacheb, H., Houas, A., Ksibi, M., Elaloui, E. and Herrmann, J.M. (2003) Influence of Chemical Structure

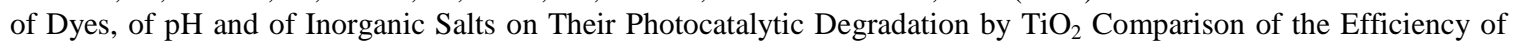
Powder and Supported $\mathrm{TiO}_{2}$. Journal of Photochemistry and Photobiology A: Chemistry, 158, 27-36. http://dx.doi.org/10.1016/S1010-6030(03)00016-9

[25] Senthilkumaar, S. and Porkodi, K. (2005) Heterogeneous Photocatalytic Decomposition of Crystal Violet in UV Illuminated Sol-Gel Derived Nanocrystalline $\mathrm{TiO}_{2}$ Suspension. Journal of Colloid and Interface Science, 288, 184-189. http://dx.doi.org/10.1016/j.jcis.2005.02.066

[26] Liu, C.C., Hsieh, Y.H., Lai, P.F., Li, C.H. and Kao, C.L. (2006) Photodegradation Treatment of Azo Dye Wastewater by $\mathrm{UV} / \mathrm{TiO}_{2}$ Process. Dyes Pigments, 68, 191-195. http://dx.doi.org/10.1016/j.dyepig.2004.12.002

[27] Zhao, H., Xu, S., Zhong, J. and Bao, X. (2004) Kinetic Study on the Photocatalytic Degradation of Pyridine in TiO ${ }_{2}$ Suspension Systems. Cataylsis Today, 93-95, 857-861. http://dx.doi.org/10.1016/j.cattod.2004.06.086

[28] Qourzal, S., Tamimi, M., Assabbane, A. and Ait-Ichou, Y. (2005) Photocatalytic Degradation and Adsorption of 2Naphthol on Suspended $\mathrm{TiO}_{2}$ Surface in a Dynamic Reactor. Journal of Colloid and Interface Science, 286, 621-626. http://dx.doi.org/10.1016/j.jcis.2005.01.046

[29] Kansal, S.K., Kaur, N. and Singh, S. (2009) Photocatalytic Degradation of Two Commercial Reactive Dyes in Aqueous Phase Using Nanophotocatalysts. Nanoscale Research Letters, 4, 709-716. http://dx.doi.org/10.1007/s11671-009-9300-3

[30] Barka, N., Assabbane, A., Nounah, A. and Ait-Ichou, Y. (2008) Photocatalytic Degradation of Indigo Carmine in Aqueous Solution by $\mathrm{TiO}_{2}$-Coated Non-Woven Fibers. Journal of Hazardous Materials, 152, 1054-1059. http://dx.doi.org/10.1016/j.jhazmat.2007.07.080

[31] Rauf, M.A. and Ashraf, S.S. (2009) Fundamental Principles and Application of Heterogeneous Photocatalytic Degradation of Dyes in Solution. Chemical Engineering Journal, 151, 10-18. http://dx.doi.org/10.1016/j.cej.2009.02.026

[32] Qourzal, S., Tamimi, M., Assabbane, A. and Ait-Ichou, Y. (2007) $\mathrm{TiO}_{2}$ Photocatalytic Mineralization of $\beta$-Naphthol: Influence of Some Inorganic Ions, Ethanol, and Hydrogen Peroxide. Comptes Rendus Chimie, 10, 1187-1194. http://dx.doi.org/10.1016/j.crci.2007.06.011

[33] Muruganandham, M., Sobana, N. and Swaminathan, M. (2006) Solar Assisted Photocatalytic and Photochemical Degradation of Reactive Black 5. Journal of Hazardous Materials, 137, 1371-1376. http://dx.doi.org/10.1016/j.jhazmat.2006.03.030

[34] Saien, J., Delavari, H. and Solymani, A.R. (2010) Sono-Assisted Photocatalytic Degradation of Styrene Acrylic Acid Copolymer in Aqueous Media with Nano Titania Particles and Kinetic Studies. Journal of Hazardous Materials, 177, 1031-1038. http://dx.doi.org/10.1016/j.jhazmat.2010.01.024

[35] Djokić, V., Vujović, J., Marinković, A., Petrović, R., Janaćković, D., Onjia, A. and Mijin, D. (2012) A Study of the Photocatalytic Degradation of the Textile Dye CI Basic Yellow 28 in Water Using a P160 $\mathrm{TiO}_{2}$-Based Catalyst. Journal of the Serbian Chemical Society, 77, 1747-1757. http://dx.doi.org/10.2298/JSC121015130D

[36] Barka, N., Qourzal, S., Assabbane, A., Nounah, A. and Ait-Ichou, Y. (2008) Factors Influencing the Photocatalytic Degradation of Rhodamine B by $\mathrm{TiO}_{2}$-Coated Non-Woven Paper. Journal of Photochemistry and Photobiology A: Chemistry, 195, 346-351. http://dx.doi.org/10.1016/j.jphotochem.2007.10.022

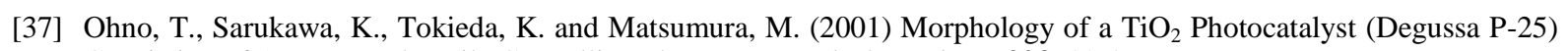
Consisting of Anatase and Rutile Crystalline Phases. Journal of Catalysis, 203, 82-86. http://dx.doi.org/10.1006/jcat.2001.3316

[38] Qourzal, S., Barka, N., Belmouden, M., Abaamrane, A., Alahiane, S., El Ouardi, M., Assabbane, A. and Ait-Ichou, Y. (2012) Heterogeneous Photocatalytic Degradation of 4-Nitrophnol on Suspended Titania Surface in a Dynamic Photoreactor. Fresenius Environmental Bulletin, 21, 1972-1981.

[39] Lucas Vas, J.L., Boussaoud, A., Ait-Ichou, Y. and Petit-Ramel, M. (1998) Photominéralisation de l'uracile et des 5-halogeno-uraciles sur le dioxyde de titane. Effet du pH et de quelques anions sur la photodégradation de l'uracile. Analusis, 26, 83-87. http://dx.doi.org/10.1051/analusis:1998115 